\title{
Structural Analysis of Affecting Factors for Future Development of Green Spaces in Tabriz City
}

\author{
Raziyeh Teimouri ${ }^{1} \&$ Hamid Hodjati ${ }^{1}$ \\ ${ }^{1}$ Geography and Urban Planning, Tabriz University, Tabriz, Iran \\ Correspondence: Raziyeh Teimouri, Geography and Urban Planning from Tabriz University, Tabriz, Iran. Tel: \\ 98-91-4913-9045. E-mail: Raziehteimouri@yahoo.com
}

Received: January 1, 2017

doi:10.5539/ass.v13n3p185
Accepted: January 19, $2017 \quad$ Online Published: February 21, 2017

URL: https://doi.org/10.5539/ass.v13n3p185

\begin{abstract}
This paper attempts to analyze factors involved in the development of urban green spaces with a systematic and structural approach and extract the most important factors for the optimal development of urban green spaces using relationships between these factors. This applied study was conducted using a descriptive analytical method, which attempted to present solutions to structural development of green spaces in Tabriz City as a case study. This study's findings can be generalized on cities with same condition. Thus, in order to achieve this goal, all factors involved in the development of green spaces have been initially extracted using Delphi method. Then, analysis of factors that have been extracted from MICMAC, relevance of factors involved in the development of green spaces in the city of Tabriz have been analyzed and finally key factors were determined. Eleven factors have identified as key factors that have important role in development of optimal green spaces in Tabriz city.
\end{abstract}

Keywords: Structural Analysis, Development, Green space, Tabriz City

\section{Introduction}

Urban green spaces are nature survivors in cities, which suffer from qualitative and quantitative changes as a result of improper urban developments. Moreover, these developments are associated with many ecological, economic and social effects (Jim, 2008). With the increasing city's depletion of the irreparable capital of natural elements as well as due to increasing destruction of green spaces and eventually quality degradation and natural performance of cities' ecosystems, ecologists have found that to solve real problems of today's world, it is essential to focus on perspectives of man dominance, which often include urban perspectives (Johnson and Hill, 2002). Presence of nature in the form of natural, open and green lands in cities should benefit from necessary physical relevance with spatial extent, composition and distribution and must be interwoven with city in such a way that they are inseparable from each other in optimal conditions, and in fact it covers cities (Tjallingi, 2003).

Importance of urban green spaces is widely recognized in all societies in social performance, biodiversity conservation and other ecological processes for eco-friendly development. Increasingly, former urban planning methods paid less insufficient attention to environment and environment surrounding cities, which led to much criticism (Gomez \& Salvador, 2006). To confirm multiple roles of green spaces, a certain level of quality development and distribution of green spaces in urban areas should be considered, which is considered part of environmental sustainability agenda. Achieving this goal requires an integrated approach and a structure in relation to planning, monitoring, design and protecting urban green spaces to improve environmental sustainability in cities (Md \& Haq, 2011). Today, green space planning has become a priority in urban planning and requires an integrated approach to achieving sustainable urban environment (Waldheim, 2006). In urbanization processes, natural features such as vegetation and natural soil are replaced with building materials for constructing residential areas, commercial buildings, roads and parking lots, to the extent that today, there is no optimal balance between green space area and open areas between urban networks and land natural patterns (Thaiutsa et al., 2008). Results of studies on land use changes from 1976 to 2006 in the city of Tabriz indicate that during 30 years, area of 6970.99 hectares has been allocated to construction, a total of $1542.57 \mathrm{~h}$ of which was constructed on city's green spaces and orchards. Actually During this period, $26.07 \%$ of this use type was destroyed in the city of Tabriz and was turned into profitable uses (Rahimi, 2013). During this period, green space per capita of about 14 square meters reached to 7.5 square meters (Beheshti roy, 2012). Also, over a period of 10 years (from 2001 to 2011), green spaces and orchards with an area of 165 hectares, approved by Article 5 
of intracity texture change have been repurposed to other land uses such as housing, roads, sports, etc (Rahimi, 2013). Process of dealing with urban green spaces from earlier times indicates that if this trend continues, destruction and use changes of green spaces, orchards and farmlands will lead to a terrible threat to sustainable development and thereby unbalancing ecological system in Tabriz (and perhaps at the regional level).

With regards to increasing population's demand for urban lands, some ecological and environmental functions move towards proportionating quality of life for human populations ( $\mathrm{Li}, 2004)$. Therefore, in urbanization processes, natural features such as vegetation and natural soils will be replaced with building materials for construction of residential areas, commercial buildings, roads and parking lots, to the extent that today there is no optimal balance between green space surface and open areas between urban networks and natural patterns (Thaiutsa, 2008). Moreover, urban networks are dominating ecological networks, which in itself lead to a ground for loss of green spaces within the city and use change of such lands, which may lead to global environmental problems such as formation of urban heat islands.

In mean time, green spaces play a significant role in supporting urban social and ecological systems (Barbosa et al., 2007). Therefore, special attention must be paid to the promotion of ecological green spaces in order to improve their productivity, because within cities, valuable ecological elements are increasingly reduced (Zangiabadi \& Rakhshani nasab, 2009). Accordingly, experts believe that one of the main ways to deal with urbanization problems is to strengthen relationship between urban people with nature (Shahivandi, 2006). Today, cities require particular attention in terms of restoration of urban nature. Because presence of nature in necessary and sufficient size, composition and distribution in cities is considered one of sustainable development requirements, which is very important to improving quality of life in urban areas and makes these areas sustainable ecologically (Alizadeh \& Salehifard, 2008). Based on structural and functional relationship principle, correlations between structural components and natural issues are modified when presence of components and relationship between main components has proper spatial structure in the context (Forman \& Godron, 1986).

Structural analysis is one of the most used tools in futures studies. Structural analysis experienced since the middle of the 1980's an increasing number of application in various domains, within business as well as on society related topics (Arcade and et al., 2003). In long term view, decision makers need to justifiable anticipation for the major drivers that may effect on their domain key variables (Omran, Khorish, \& Saleh, 2014). Therefore, this paper indicates the structural analysis for identifying the key factors in future development of Tabriz City's green spaces by answering to following question:

Which variables involved in development of green space of Tabriz city? And which of them has more influence on development of green space?

\section{Methodology}

Structural analysis seeks to identify key variables (overt and covert) in order to get feedbacks and encourage participants and beneficiaries on aspects and complex and unpredictable behavior of the system.

Structural analysis method is a tool for linking ideas and thoughts, which operates through correlation matrix of all system variables. This model is able to identify relationships between variables and eventually identify key variables affecting the system evolution. Structural analysis methods is among methods, which analyzes the relationships between variables and different components of a system and its output is effective in investigating relationships between variables and identifying their characteristics (Rabani, 2012). In this research, variables involved in the future development of green spaces in City of Tabriz are estimated using Delphi method. Then, structure of green spaces development in the city of Tabriz was analyzed using MICMAC software and key factors were extracted. It is worth mentioning that prediction method of "MICMAC" was invented by Michael Godet. He summarized the prediction method in the following steps:

\section{Step 1: Evaluation of variables}

The first phase includes a review of all variables detected within the intended system (internal and external variables); It should be noted that all variables are taken into account comprehensively. Use of experts' views helps expand set of variables and consider all potential actors in the intended system.

\section{Step 2: Investigation of correlation between variables}

In a structural analysis, there is possible of correlating between variables in a two-row table (direct correlation). Correlation degree of two variables is shown quantitatively. 0 means that there is no correlation between two variables and the amount of effect of variables can also be shown with corresponding numbers $(0=$ no correlation $1=$ poor correlation, 2 = moderate correlation, $3=$ strong correlation). At this stage, we will face variable $\mathrm{N}$ and $\mathrm{N} \times \mathrm{N}$ questions (almost 5,000 questions for 70 variables), some of which will be discarded 
without having systematic and comprehensive effect.

\section{Step 3: Identification of key variables}

This step includes identification of key variables, which is done using direct and indirect classifications.

Definition of direct classification: All relationships in a row reflect importance of a variable's effect on the whole system. Sum of a column represents affectability amount of a variable (level of direct affectability).

Definition of indirect classification: This program allows you to study effect expansion using path and feedback loops and eventually classify variables.

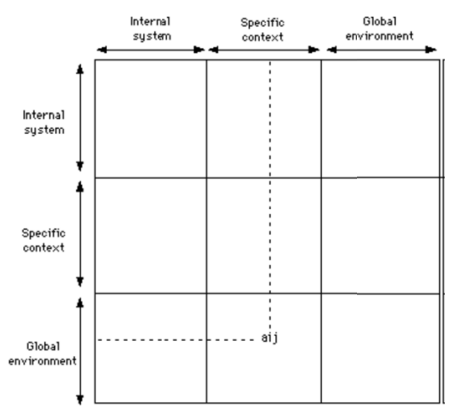

Figure (1). Structural analysis matrix

Source: Godet, 2012, 15

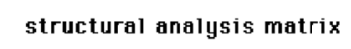

spontaneous graph
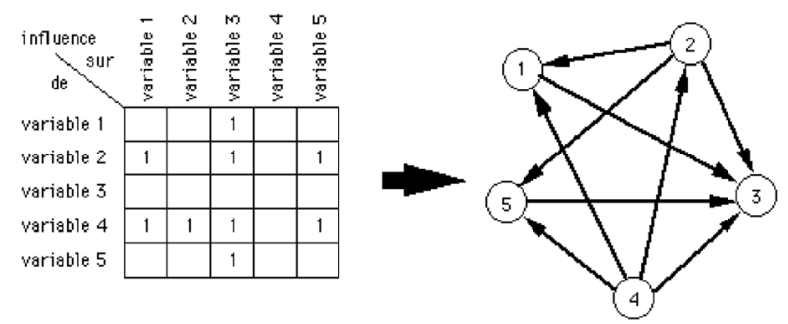

Figure (2). Structural analysis matrix and its diagram

Source: Godet, 2012, 15

\section{Introduction of the Study Area}

Tabriz city is the northwest hub in Iran in terms of population, industry, education and health. According to 2011 population and housing census, city of Tabriz has a population of 1,494,998 people.

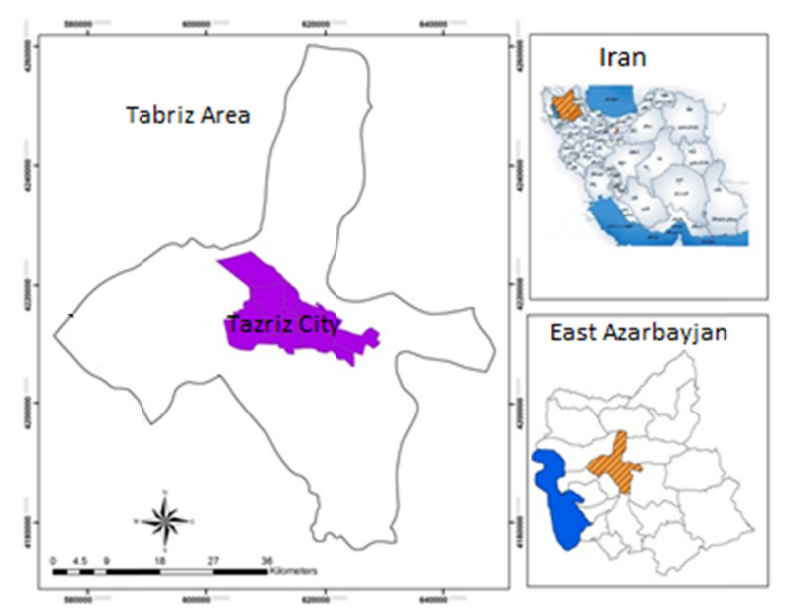

Figure (3). Geographic locating of Tabriz City

Source: compiled by author 
Physical development of Tabriz metropolitan always leads to disappearance of orchards and urban green spaces. Tabriz city, which was once surrounded in midst of orchards and enjoyed rich agricultural lands in the city outskirt, has lost majority of them in favor of urban and often unnecessary construction by wrong government decisions in the form of urban development planning. Results of investigations in the last three decades indicate that rapid population growth and dominance of economic perspective to lands was associated with further expansion of metropolitan area of Tabriz in non-prone lands and destruction of agricultural and horticultural lands (Mahmoodzadeh, 2014: 175). Overall, parks and green spaces area in the city of Tabriz is 1333.88 hectares, which are dispersed across the city in an unbalanced and mostly peripheral ways.

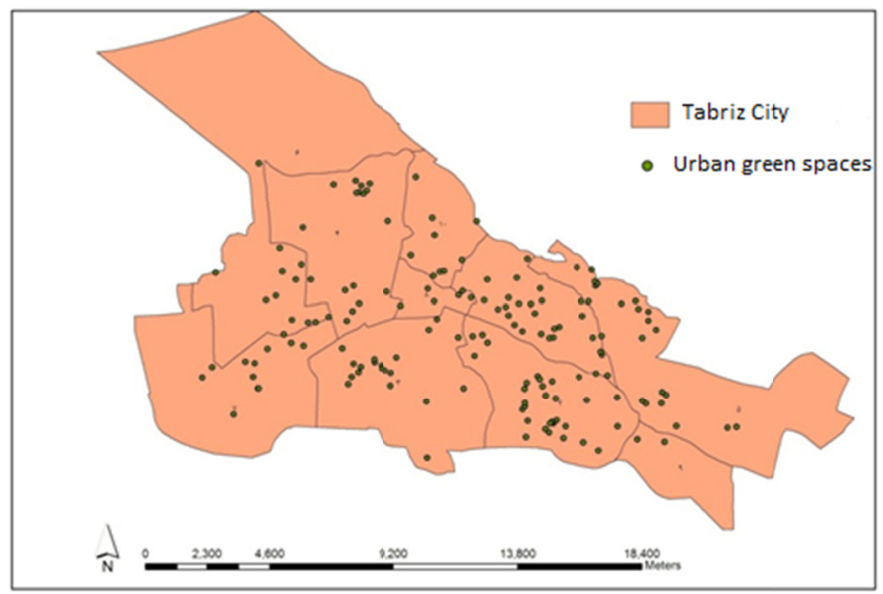

Figure (4). Dispersion of green spaces in Tabriz

Source: compiled by author

\section{Results and Discussion}

\subsection{Opinion Polling Experts Using Delphi Method}

In this study, to identify primary variables affecting future development of green spaces in the city of Tabriz, Delphi method is used as follows: First, experts and executives involved in the studied field were identified and selected. In this study, all specialists and experts in the green spaces development field, including university professors and parks staff as well as green space staff of ten municipality districts in Tabriz were surveyed (50 persons responded). After participants were selected, their views on future development of green spaces in city of Tabriz were surveyed and extracted. Finally, after monitoring variables, a total of 51 variables under six general factors (natural, socio - cultural, physical, environmental, economic and urban landscape) were selected as primary variables affecting the future development of green spaces in Tabriz.

Table (1). Factors affecting structural development of urban green spaces

\begin{tabular}{|c|c|c|c|}
\hline Variable name & $\frac{\tilde{z}}{\tilde{J}}$ & Variable name & $\begin{array}{l}n \\
\substack{0 \\
U}\end{array}$ \\
\hline Average annual precipitation & \multirow{10}{*}{ 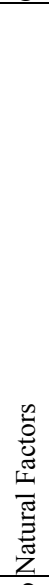 } & $\begin{array}{l}\text { Allocating specific budget on behalf of urban } \\
\text { management }\end{array}$ & \multirow{10}{*}{ 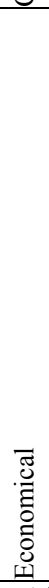 } \\
\hline Available water resources & & $\begin{array}{l}\text { Use of appropriate agricultural land for economic } \\
\text { savings in the long run }\end{array}$ & \\
\hline Soil texture and depth & & $\begin{array}{l}\text { Acquisition and purchase of land in different places of } \\
\text { the city }\end{array}$ & \\
\hline Vegetation natural density & & Mutual planning for green spaces in the outskirt area & \\
\hline Average annual temperature & & $\begin{array}{l}\text { Investment in the development and protection of green } \\
\text { spaces }\end{array}$ & \\
\hline Prevailing wind speed & & $\begin{array}{l}\text { Provision of infrastructure for green spaces construction } \\
\text { by the urban management }\end{array}$ & \\
\hline Prevailing wind direction & & $\begin{array}{l}\text { Increase the economic efficiency of green spaces and in } \\
\text { different parts of city centers and outskirts }\end{array}$ & \\
\hline Humidity percentage & & \multirow{3}{*}{$\begin{array}{l}\text { Temporal variety in using green spaces, especially in } \\
\text { cold seasons }\end{array}$} & \\
\hline Earth's tilt & & & \\
\hline area of natural green spaces & & & \\
\hline Construction and development of green promenade & $\stackrel{\circ}{\infty}$ & Adequate and balanced distribution across the city & $\frac{1}{2}$ \\
\hline
\end{tabular}




\begin{tabular}{|c|c|c|c|}
\hline Green spaces maintenance and protection & & Forestry development within and outside the city limits & \\
\hline Equipping green spaces with recreational function & & Construction of the green belt in suburbs & \\
\hline Continuous use of green spaces & & Design and implementation of water supply networks & \\
\hline Proper for access to all citizens & & $\begin{array}{l}\text { Development of street green spaces (refuge, lawn and } \\
\text { flower planting ...) }\end{array}$ & \\
\hline Training and Strengthening public awareness in order to protect & & Construction of mountainous parks & \\
\hline green space development & & Diversification of green spaces functions & \\
\hline $\begin{array}{l}\text { The use of appropriate genetic technologies on Plants for adaptation } \\
\text { to climate }\end{array}$ & & $\begin{array}{l}\text { Proper location for the ecological development of green } \\
\text { spaces }\end{array}$ & \\
\hline $\begin{array}{l}\text { Public participation in conservation and development of green } \\
\text { spaces }\end{array}$ & & & \\
\hline Natural and man-made attraction of green spaces & & & \\
\hline Provision of security, equipment and facilities in public green spaces & & & \\
\hline Managerial and institutional factors & & & \\
\hline Organization of ecological networks (river, stream, watercourse, ...) & \multirow{7}{*}{ 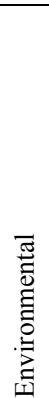 } & Continuity of green spots & \multirow{7}{*}{ 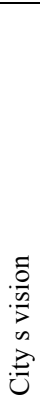 } \\
\hline $\begin{array}{l}\text { Sustainable water resources (rivers, springs, water treatment plants, } \\
\text { etc.) }\end{array}$ & & $\begin{array}{l}\text { Presence large spots of green spaces in four corners of } \\
\text { the city }\end{array}$ & \\
\hline $\begin{array}{l}\text { Biodiversity (using native species compatible with Tabriz } \\
\text { environment, providing green spaces suitable for native animals) }\end{array}$ & & $\begin{array}{l}\text { Observing the structure of green spots (linear, point } \\
\text { wise and polygon) }\end{array}$ & \\
\hline Appropriate locating with regard to prevailing wind & & Planting of various plant species & \\
\hline $\begin{array}{l}\text { Appropriate locating with regard to the reduction of environmental } \\
\text { pollution }\end{array}$ & & Beautification and design of green spaces & \\
\hline Dense planting of vegetation & & Vertical green spaces (green roofs, green walls) & \\
\hline Using trees instead of grasses and drought-resistant species & & $\begin{array}{l}\text { Attaching importance to green scenery in and around } \\
\text { the city }\end{array}$ & \\
\hline
\end{tabular}

Source: compiled by author

\subsection{General Analysis of System Environment}

According to Delphi method mentioned above, a total of 51 variables in 6 areas were identified as factors affecting future development of ecological green space of Tabriz metropolitan and were studied and analyzed using cross-impact and structural analysis by MICMAC Software to extract main factors affecting future status of green spaces. Based on number of variables, a matrix with dimensions of 51 x 51 is used. By placing these factors in a 51x51 matrix, effect of each of these factors on each other was identified by weighting factors (from 0 to 3). All factors involved in planning of urban green spaces are considered as a system with intertwined elements and in the form of one structure and the relationship between these factors is measured so as to extract superior factors with higher effects. The number of repeated interaction between variables was considered two times and the matrix filling degree was $35.60 \%$, which shows dispersion of variables affecting development of ecological green spaces in Tabriz.

From a total of 890 evaluable relationships in this matrix, 1610 relationships are zero, 444 relationships are 1, 194 relationships are 2 and 252 relationships are 3. Also, the matrix had utility and optimization of $100 \%$ based on statistical indicators with two-time data rotations, which indicated a high validity of the questionnaire and its responses. In the following section, to analyze overall system environment and finally to identify key factors, affectability plans of variables as well as rating and displacement degree of variables are investigated.

Table (2). Initial data analysis of cross-impact matrix

\begin{tabular}{ccc}
\hline Indicator & Value \\
\hline Matrix size & 51 \\
number of interactions & 2 \\
number of zeros & 1610 \\
number of ones & 444 \\
number of twos & 194 \\
number of threes & 252 \\
Total & 890 \\
\hline
\end{tabular}

Source: compiled by author 


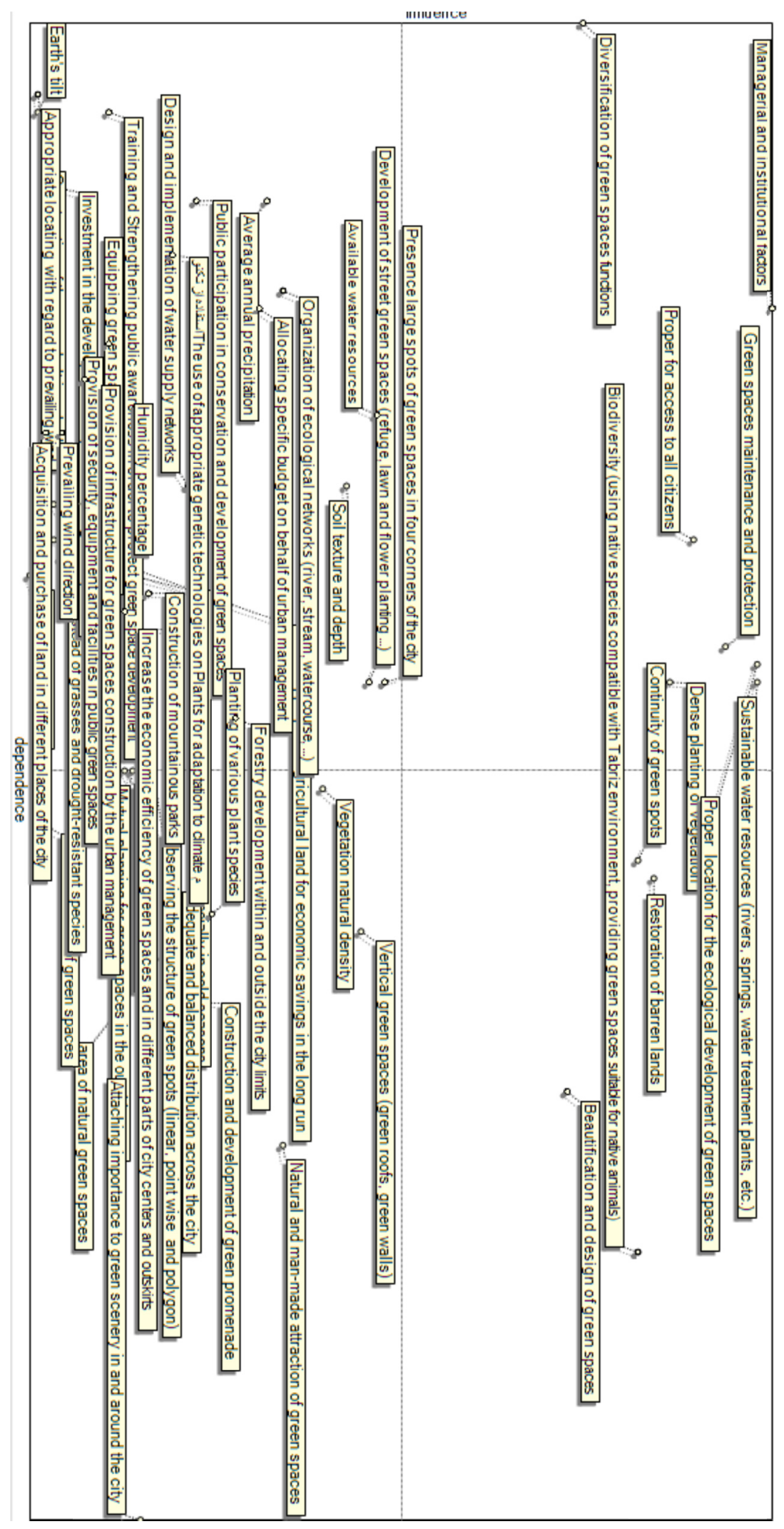

Figure (5). Dispersion of variables based on direct changes Source: compiled by author 


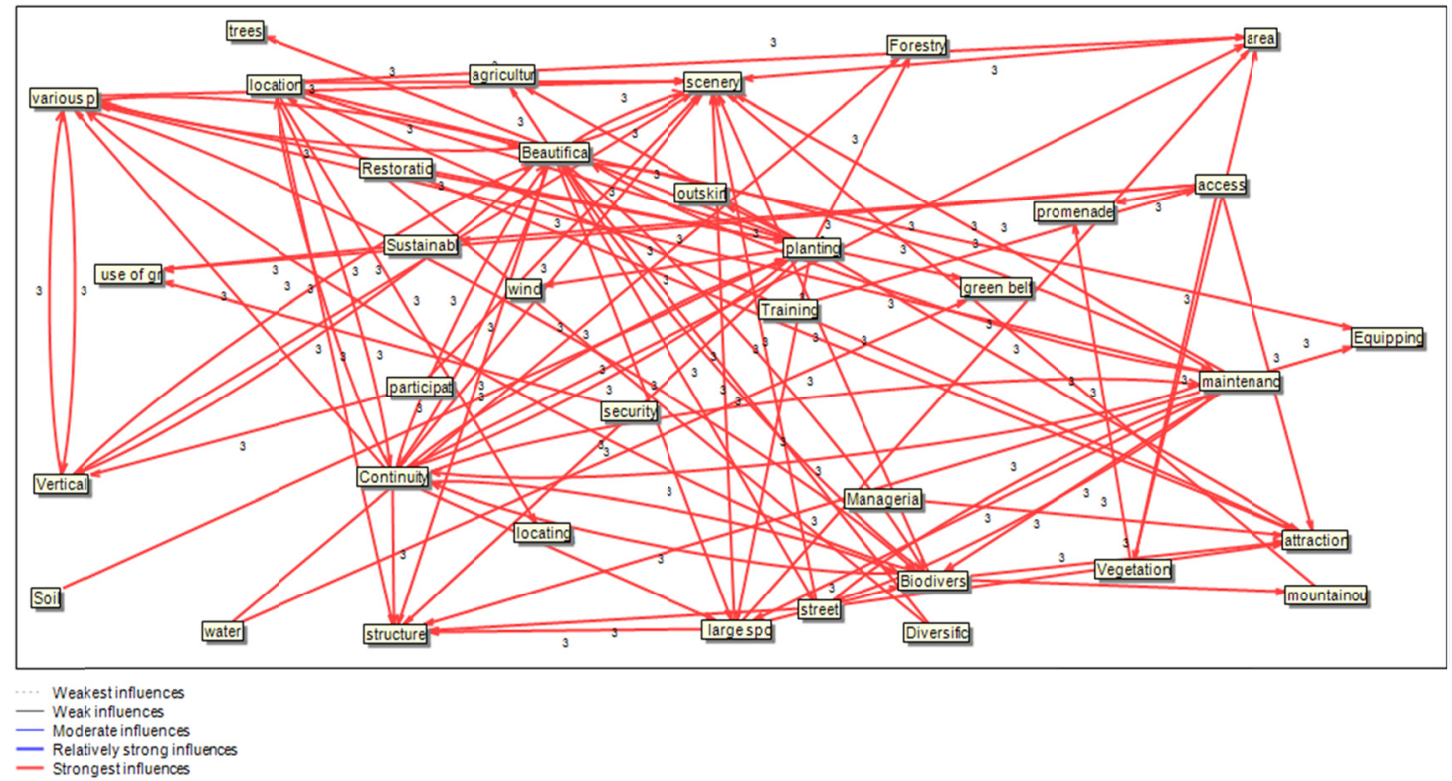

Figure (6). Direct relationships between variables (very weak to very strong effects

Source: compiled by author

The above diagram shows relationship between variables in "MICMAC" software.

\subsection{Rating of Direct and Indirect Effects of Variables}

According to the questionnaires that are completed in the form of a matrix, the software calculates the relationship between them and finally considers a numerical rating for each factor. Then, based on this rating, it ranks factors based on impact and affectability directly or indirectly, which in this case and on the basis of factors' rating, their impact and affectability rates changes. In the following table, green space development factors in Tabriz are ranked based on direct and indirect impact and affectability.

Table (3). Rating of direct and indirect effects of all envolved variables in green space development on each other

\begin{tabular}{|c|c|c|c|c|c|c|c|c|}
\hline Rank & Label & $\begin{array}{l}\text { Direct } \\
\text { influence }\end{array}$ & Label & $\begin{array}{l}\text { Direct } \\
\text { dépendance }\end{array}$ & Label & $\begin{array}{l}\text { Indirect } \\
\text { influence }\end{array}$ & Label & $\begin{array}{l}\text { Indirect } \\
\text { dependence }\end{array}$ \\
\hline 1 & Managerial factors & 572 & scenery & 506 & Managerial factors & 605 & scenery & 513 \\
\hline 2 & $\begin{array}{l}\text { Sustainable water } \\
\text { Resources }\end{array}$ & 560 & Biodiversity & 415 & Proper locating & 521 & Biodiversity & 417 \\
\hline 3 & Proper locating & 560 & $\begin{array}{l}\text { Attraction } \\
\text { increasing }\end{array}$ & 379 & $\begin{array}{l}\text { Sustainable water } \\
\text { Resources }\end{array}$ & 516 & $\begin{array}{l}\text { Attraction } \\
\text { increasing }\end{array}$ & 414 \\
\hline 4 & maintenance & 536 & Beautification & 361 & Proper access & 506 & Beautification & 377 \\
\hline 5 & Proper access & 512 & promenade & 331 & Continuity & 501 & promenade & 324 \\
\hline 6 & Dense planting & 494 & & 307 & maintenance & 499 & $\begin{array}{l}\text { Balanced } \\
\text { distribution }\end{array}$ & 301 \\
\hline 7 & $\begin{array}{l}\text { Restoration of } \\
\text { barren lands }\end{array}$ & 482 & Vertical GS & 307 & $\begin{array}{l}\text { Restoration of } \\
\text { barren lands }\end{array}$ & 481 & $\begin{array}{l}\text { Restoration of } \\
\text { barren lands }\end{array}$ & 298 \\
\hline 8 & Biodiversity & 470 & various specious & 301 & $\begin{array}{l}\text { Diversification of } \\
\text { GS applications }\end{array}$ & 434 & Vertical GS & 296 \\
\hline 9 & $\begin{array}{l}\text { Green space } \\
\text { continuity }\end{array}$ & 470 & $\begin{array}{l}\text { Restoration of } \\
\text { barren lands }\end{array}$ & 289 & Beautification & 432 & various specious & 289 \\
\hline 10 & $\begin{array}{l}\text { Diversification of } \\
\text { GS applications }\end{array}$ & 427 & $\begin{array}{l}\text { Balanced } \\
\text { distribution }\end{array}$ & 289 & Biodiversity & 421 & Continuous use & 288 \\
\hline 11 & Beautification & 415 & $\begin{array}{l}\text { Continuity of } \\
\text { green space }\end{array}$ & 283 & Dense planting & 406 & $\begin{array}{l}\text { Continuity } \\
\text { green space }\end{array}$ & 283 \\
\hline 12 & $\begin{array}{l}\text { Large patches of } \\
\text { GS }\end{array}$ & 277 & Continuous use & 271 & Water resources & 299 & area of natural GS & 274 \\
\hline 13 & Water resources & 271 & Naturally covered & 259 & Vertical GS & 298 & $\begin{array}{l}\text { the structure of } \\
\text { green spots (linear, }\end{array}$ & 258 \\
\hline
\end{tabular}




\begin{tabular}{|c|c|c|c|c|c|c|c|c|}
\hline & & & & & & & point ,polygon) & \\
\hline 14 & street GS & 265 & $\begin{array}{l}\text { The average of } \\
\text { annual temperature }\end{array}$ & 253 & $\begin{array}{l}\text { Texture and depth } \\
\text { of soil }\end{array}$ & 278 & $\begin{array}{l}\text { The average of } \\
\text { annual temperature }\end{array}$ & 244 \\
\hline 15 & Vertical GS & 259 & $\begin{array}{l}\text { Mutual GS } \\
\text { planning in } \\
\text { surrounding areas }\end{array}$ & 253 & street GS & 277 & $\begin{array}{lr}\text { Mutual GS } \\
\text { planning in } \\
\text { surrounding areas }\end{array}$ & 244 \\
\hline 16 & $\begin{array}{l}\text { Texture and depth } \\
\text { of soil }\end{array}$ & 247 & $\begin{array}{l}\text { the structure of } \\
\text { green spots (linear, } \\
\text { point ,polygon) }\end{array}$ & 241 & $\begin{array}{l}\text { Large patches of } \\
\text { GS }\end{array}$ & 236 & Proper locating & 237 \\
\hline 17 & Naturally covered & 229 & $\begin{array}{l}\text { Forestry } \\
\text { development }\end{array}$ & 235 & Naturally covered & 235 & Naturally covered & 236 \\
\hline 18 & $\begin{array}{l}\text { Attraction } \\
\text { increasing }\end{array}$ & 198 & $\begin{array}{l}\text { Sustainable water } \\
\text { Resources }\end{array}$ & 223 & $\begin{array}{l}\text { Attraction } \\
\text { increasing }\end{array}$ & 231 & $\begin{array}{l}\text { Large patches of } \\
\text { GS }\end{array}$ & 232 \\
\hline 19 & $\begin{array}{l}\text { Organization of } \\
\text { ecological } \\
\text { networks }\end{array}$ & 198 & Dense planting & 223 & $\begin{array}{l}\text { Organization of } \\
\text { ecological } \\
\text { networks }\end{array}$ & 223 & maintenance & 229 \\
\hline 20 & $\begin{array}{l}\text { Average annual } \\
\text { precipitation }\end{array}$ & 186 & street GS & 223 & $\begin{array}{l}\text { Allocating specific } \\
\text { budget }\end{array}$ & 186 & street GS & 227 \\
\hline 21 & $\begin{array}{l}\text { Allocating specific } \\
\text { budget }\end{array}$ & 180 & $\begin{array}{l}\text { Large patches of } \\
\text { GS }\end{array}$ & 223 & $\begin{array}{l}\text { Average annual } \\
\text { precipitation }\end{array}$ & 176 & Dense planting & 221 \\
\hline 22 & $\begin{array}{l}\text { Forestry } \\
\text { development }\end{array}$ & 162 & Proper locating & 216 & various specious & 173 & $\begin{array}{l}\text { Equipping green } \\
\text { spaces }\end{array}$ & 220 \\
\hline 23 & various specious & 144 & maintenance & 210 & $\begin{array}{l}\text { Forestry } \\
\text { development }\end{array}$ & 157 & $\begin{array}{l}\text { Increase the } \\
\text { economic } \\
\text { efficiency }\end{array}$ & 219 \\
\hline 24 & $\begin{array}{l}\text { development of } \\
\text { green promenade }\end{array}$ & 138 & $\begin{array}{l}\text { Increase the } \\
\text { economic } \\
\text { efficiency }\end{array}$ & 204 & $\begin{array}{l}\text { Balanced } \\
\text { distribution }\end{array}$ & 152 & $\begin{array}{l}\text { Forestry } \\
\text { development }\end{array}$ & 219 \\
\hline 25 & $\begin{array}{l}\text { Public } \\
\text { participation in } \\
\text { conservation and } \\
\text { development of GS }\end{array}$ & 132 & $\begin{array}{l}\text { Equipping green } \\
\text { spaces }\end{array}$ & 198 & $\begin{array}{l}\text { development of } \\
\text { green promenade }\end{array}$ & 150 & $\begin{array}{l}\text { Sustainable water } \\
\text { Resources }\end{array}$ & 219 \\
\hline 26 & $\begin{array}{l}\text { Design of water } \\
\text { supply networks }\end{array}$ & 126 & $\begin{array}{l}\text { Construction of } \\
\text { mountainous parks }\end{array}$ & 192 & $\begin{array}{l}\text { Public } \\
\text { participation in } \\
\text { conservation and } \\
\text { development of GS }\end{array}$ & 138 & $\begin{array}{l}\text { Construction of } \\
\text { mountainous parks }\end{array}$ & 197 \\
\hline 27 & area of natural GS & 120 & $\begin{array}{l}\text { Prevailing wind } \\
\text { speed }\end{array}$ & 186 & $\begin{array}{l}\text { the structure of } \\
\text { green spots (linear, } \\
\text { point,polygon) }\end{array}$ & 131 & $\begin{array}{l}\text { Temporal variety } \\
\text { in using GS }\end{array}$ & 193 \\
\hline 28 & $\begin{array}{l}\text { The use of } \\
\text { appropriate genetic } \\
\text { technologies on } \\
\text { Plants }\end{array}$ & 114 & $\begin{array}{l}\text { Humidity } \\
\text { percentage }\end{array}$ & 180 & $\begin{array}{l}\text { The use of } \\
\text { appropriate genetic } \\
\text { technologies on } \\
\text { Plants }\end{array}$ & 123 & $\begin{array}{l}\text { Prevailing wind } \\
\text { speed }\end{array}$ & 177 \\
\hline 29 & $\begin{array}{l}\text { Increase the } \\
\text { economic } \\
\text { efficiency }\end{array}$ & 114 & $\begin{array}{l}\text { Temporal variety } \\
\text { in using GS }\end{array}$ & 180 & scenery & 119 & $\begin{array}{l}\text { Use of appropriate } \\
\text { agricultural land } \\
\text { for economic } \\
\text { savings }\end{array}$ & 169 \\
\hline 30 & $\begin{array}{l}\text { Balanced } \\
\text { distribution }\end{array}$ & 114 & Proper access & 174 & $\begin{array}{l}\text { Design of water } \\
\text { supply networks }\end{array}$ & 118 & $\begin{array}{l}\text { Humidity } \\
\text { percentage }\end{array}$ & 168 \\
\hline 31 & $\begin{array}{l}\text { Construction of } \\
\text { mountainous parks }\end{array}$ & 96 & $\begin{array}{l}\text { Use of appropriate } \\
\text { agricultural land } \\
\text { for economic } \\
\text { savings }\end{array}$ & 174 & area of natural GS & 110 & Proper access & 166 \\
\hline 32 & $\begin{array}{l}\text { the structure of } \\
\text { green spots (linear, } \\
\text { point ,polygon) }\end{array}$ & 96 & $\begin{array}{l}\text { Using trees instead } \\
\text { of grasses }\end{array}$ & 162 & $\begin{array}{l}\text { Increase the } \\
\text { economic } \\
\text { efficiency }\end{array}$ & 91 & $\begin{array}{l}\text { Texture and depth } \\
\text { of soil }\end{array}$ & 157 \\
\hline 33 & scenery & 90 & $\begin{array}{l}\text { Construction of the } \\
\text { green belt in } \\
\text { suburbs }\end{array}$ & 162 & $\begin{array}{l}\text { Construction of } \\
\text { mountainous parks }\end{array}$ & 87 & $\begin{array}{l}\text { Construction of the } \\
\text { green belt in } \\
\text { suburbs }\end{array}$ & 154 \\
\hline 34 & $\begin{array}{l}\text { Mutual GS } \\
\text { planning in } \\
\text { surrounding areas }\end{array}$ & 84 & $\begin{array}{l}\text { Texture and depth } \\
\text { of soil }\end{array}$ & 156 & $\begin{array}{l}\text { The average of } \\
\text { annual temperature }\end{array}$ & 78 & $\begin{array}{l}\text { Acquisition and } \\
\text { purchase of land in } \\
\text { different places of } \\
\text { the city }\end{array}$ & 153 \\
\hline
\end{tabular}




\begin{tabular}{|c|c|c|c|c|c|c|c|c|}
\hline 35 & $\begin{array}{l}\text { The average of } \\
\text { annual temperature }\end{array}$ & 78 & $\begin{array}{l}\text { Design of water } \\
\text { supply networks }\end{array}$ & 156 & $\begin{array}{l}\text { Training public } \\
\text { awareness in order } \\
\text { to protect GS }\end{array}$ & 72 & $\begin{array}{l}\text { Using trees instead } \\
\text { of grasses }\end{array}$ & 151 \\
\hline 36 & $\begin{array}{l}\text { Equipping green } \\
\text { spaces }\end{array}$ & 78 & $\begin{array}{l}\text { Appropriate } \\
\text { locating with } \\
\text { regard to } \\
\text { prevailing wind }\end{array}$ & 138 & $\begin{array}{l}\text { Equipping green } \\
\text { spaces }\end{array}$ & 72 & $\begin{array}{l}\text { Prevailing wind } \\
\text { direction }\end{array}$ & 138 \\
\hline 37 & $\begin{array}{l}\text { Humidity } \\
\text { percentage }\end{array}$ & 72 & $\begin{array}{l}\text { Acquisition and } \\
\text { purchase of land in } \\
\text { different places of } \\
\text { the city }\end{array}$ & 138 & $\begin{array}{l}\text { Mutual GS } \\
\text { planning in } \\
\text { surrounding areas }\end{array}$ & 67 & $\begin{array}{l}\text { Provision of } \\
\text { infrastructure for } \\
\text { GS construction }\end{array}$ & 126 \\
\hline 38 & $\begin{array}{l}\text { Training public } \\
\text { awareness in order } \\
\text { to protect GS }\end{array}$ & 66 & Water resources & 132 & $\begin{array}{l}\text { Humidity } \\
\text { percentage }\end{array}$ & 59 & Water resources & 124 \\
\hline 39 & $\begin{array}{l}\text { Provision of } \\
\text { security, and in } \\
\text { public GS }\end{array}$ & 66 & $\begin{array}{l}\text { Provision of } \\
\text { infrastructure for } \\
\text { GS construction }\end{array}$ & 120 & $\begin{array}{l}\text { Provision of } \\
\text { security, and in } \\
\text { public GS }\end{array}$ & 58 & Water resources & 121 \\
\hline 40 & $\begin{array}{l}\text { Provision of } \\
\text { infrastructure for } \\
\text { GS construction }\end{array}$ & 48 & $\begin{array}{l}\text { Provision of } \\
\text { security, and in } \\
\text { public GS }\end{array}$ & 108 & $\begin{array}{l}\text { Construction of the } \\
\text { green belt in } \\
\text { suburbs }\end{array}$ & 48 & $\begin{array}{l}\text { Allocating specific } \\
\text { budget }\end{array}$ & 111 \\
\hline 41 & $\begin{array}{l}\text { Construction of the } \\
\text { green belt in } \\
\text { suburbs }\end{array}$ & 42 & Managerial factors & 96 & $\begin{array}{l}\text { Temporal variety } \\
\text { in using GS }\end{array}$ & 40 & $\begin{array}{l}\text { The use of } \\
\text { appropriate genetic } \\
\text { technologies on } \\
\text { Plants }\end{array}$ & 108 \\
\hline 42 & $\begin{array}{l}\text { Acquisition and } \\
\text { purchase of land in } \\
\text { different places of } \\
\text { the city }\end{array}$ & 30 & $\begin{array}{l}\text { Allocating specific } \\
\text { budget }\end{array}$ & 96 & $\begin{array}{l}\text { Provision of } \\
\text { infrastructure for } \\
\text { GS construction }\end{array}$ & 36 & $\begin{array}{l}\text { Provision of } \\
\text { security, and in } \\
\text { public GS }\end{array}$ & 108 \\
\hline 43 & $\begin{array}{l}\text { Temporal variety } \\
\text { in using GS }\end{array}$ & 30 & $\begin{array}{l}\text { Organization of } \\
\text { ecological } \\
\text { networks }\end{array}$ & 90 & $\begin{array}{l}\text { Acquisition and } \\
\text { purchase of land in } \\
\text { different places of } \\
\text { the city }\end{array}$ & 28 & $\begin{array}{l}\text { Organization of } \\
\text { ecological } \\
\text { networks }\end{array}$ & 92 \\
\hline 44 & $\begin{array}{l}\text { Using trees instead } \\
\text { of grasses }\end{array}$ & 24 & $\begin{array}{l}\text { The use of } \\
\text { appropriate genetic } \\
\text { technologies on } \\
\text { Plants }\end{array}$ & 78 & $\begin{array}{l}\text { Use of appropriate } \\
\text { agricultural land } \\
\text { for economic } \\
\text { savings }\end{array}$ & 25 & Managerial factors & 73 \\
\hline 45 & $\begin{array}{l}\text { Use of appropriate } \\
\text { agricultural land } \\
\text { for economic } \\
\text { savings }\end{array}$ & 24 & $\begin{array}{l}\text { Average annual } \\
\text { precipitation }\end{array}$ & 60 & Continuous use & 25 & $\begin{array}{l}\text { Average annual } \\
\text { precipitation }\end{array}$ & 55 \\
\hline 46 & $\begin{array}{l}\text { Appropriate } \\
\text { locating with } \\
\text { regard to } \\
\text { prevailing wind }\end{array}$ & 18 & $\begin{array}{l}\text { Public } \\
\text { participation in } \\
\text { conservation and } \\
\text { development of GS }\end{array}$ & 60 & $\begin{array}{l}\text { Using trees instead } \\
\text { of grasses }\end{array}$ & 19 & $\begin{array}{l}\text { Public } \\
\text { participation in } \\
\text { conservation and } \\
\text { development of GS }\end{array}$ & 48 \\
\hline 47 & Continuous use & 18 & $\begin{array}{l}\text { Investment in the } \\
\text { development and } \\
\text { protection }\end{array}$ & 54 & $\begin{array}{l}\text { Investment in the } \\
\text { development and } \\
\text { protection }\end{array}$ & 17 & $\begin{array}{l}\text { Investment in the } \\
\text { development and } \\
\text { protection }\end{array}$ & 38 \\
\hline 48 & $\begin{array}{l}\text { Investment in the } \\
\text { development and } \\
\text { protection }\end{array}$ & 18 & Earth's tilt & 30 & Earth's tilt & 11 & Earth's tilt & 29 \\
\hline 49 & Earth's tilt & 12 & $\begin{array}{l}\text { Training public } \\
\text { awareness in order } \\
\text { to protect GS }\end{array}$ & 30 & $\begin{array}{l}\text { Appropriate } \\
\text { locating with } \\
\text { regard to } \\
\text { prevailing wind }\end{array}$ & 8 & $\begin{array}{l}\text { Appropriate } \\
\text { locating with } \\
\text { regard to } \\
\text { prevailing wind }\end{array}$ & 23 \\
\hline 50 & $\begin{array}{l}\text { Appropriate } \\
\text { locating with } \\
\text { regard to } \\
\text { prevailing wind }\end{array}$ & 12 & $\begin{array}{l}\text { Appropriate } \\
\text { locating with } \\
\text { regard to } \\
\text { prevailing wind }\end{array}$ & 24 & $\begin{array}{l}\text { Prevailing wind } \\
\text { speed }\end{array}$ & 2 & $\begin{array}{l}\text { Training public } \\
\text { awareness in order } \\
\text { to protect GS }\end{array}$ & 20 \\
\hline
\end{tabular}

Source: compiled by author

\subsection{Displacement Degree of Factors in Case of Direct and Indirect Effects of Variables}

The following diagram shows displacement degree of factors in case of direct and indirect effects of variables. As the diagram shows, the displacement degree had not much impact on changing the position of factors. 


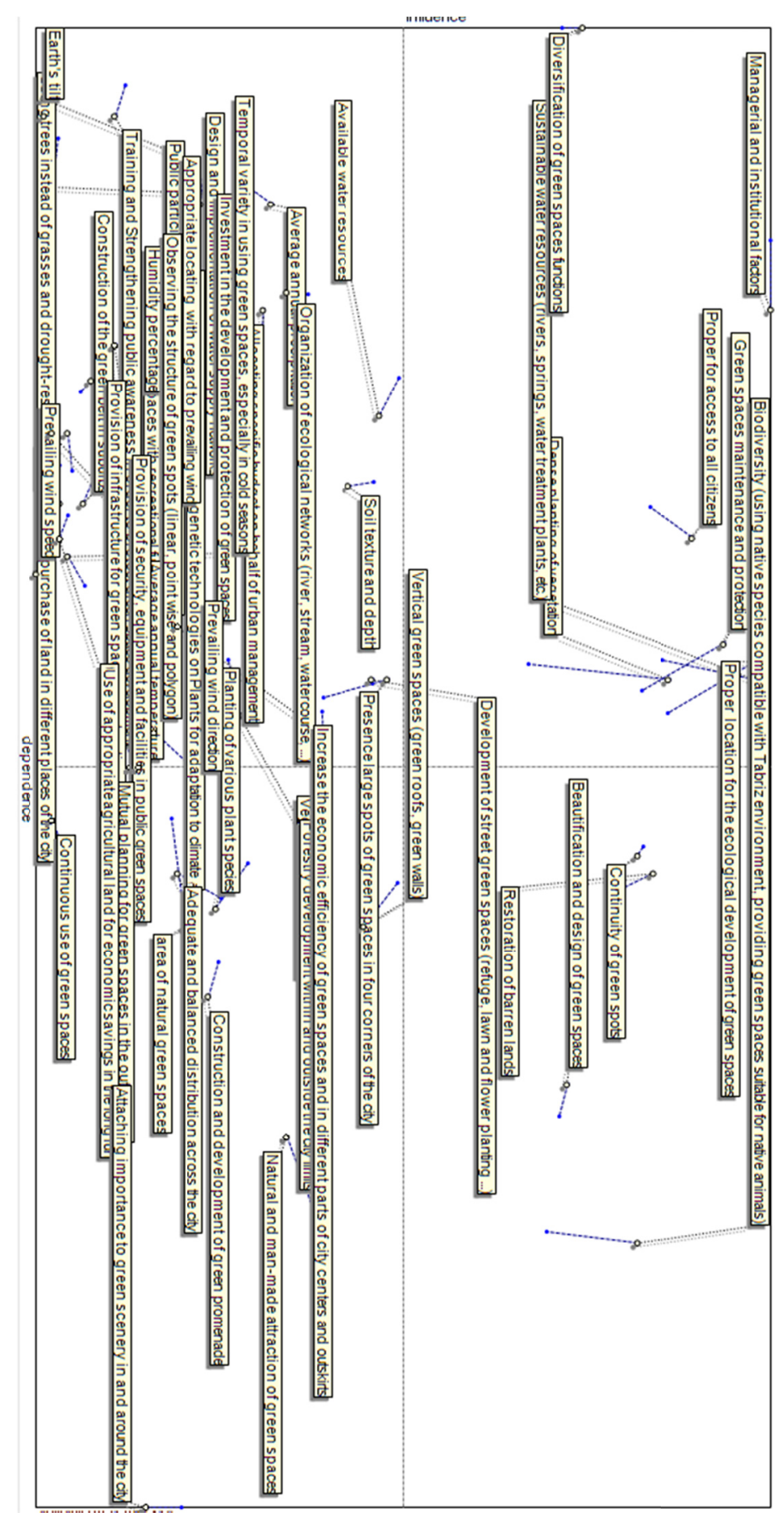

Figure (7). Displacement rate of direct and indirect effects Source: compiled by author

\subsection{Status of Green Spaces Future Development Factors in the City of Tabriz in MICMAC Diagram}

In this section, we first investigated status of factors involved in the future development of green spaces in Tabriz metropolitan and analyzed overall status of the system. According to previous discussions, a total of 51 factors were identified, their effects on each other were measured and finally a total of 11 factors were extracted as key factors affecting the future development of green spaces in Tabriz metropolitan. All of these eleven factors were repeated in both direct and indirect methods.

Key factors, according to their weight are as follows: 
Table (4). Key effective drivers (directly or indirectly)

\begin{tabular}{|c|c|c|c|c|}
\hline Number & Variable & $\begin{array}{c}\text { Direct } \\
\text { effect }\end{array}$ & Variable & $\begin{array}{c}\text { Indirect } \\
\text { effect }\end{array}$ \\
\hline 1 & Managerial and institutional factors & 572 & Managerial and institutional factors & 605 \\
\hline 2 & Sustainable water Resources & 521 & $\begin{array}{c}\text { Proper locating for ecological } \\
\text { development }\end{array}$ & 565 \\
\hline 3 & $\begin{array}{c}\text { Proper locating for the ecological } \\
\text { development }\end{array}$ & 560 & Sustainable Water Resources & 520 \\
\hline 4 & Maintenance and protection & 536 & Proper access to all citizens & 506 \\
\hline 5 & Proper access to all citizens & 512 & Green space continuity & 501 \\
\hline 6 & Dense planting & 494 & Maintenance and protection & 499 \\
\hline 7 & Restoration of barren lands & 482 & Restoration of barren lands & 481 \\
\hline 8 & Biodiversity & 470 & $\begin{array}{l}\text { Diversification of green space } \\
\text { applications }\end{array}$ & 434 \\
\hline 9 & Green space continuity & 470 & $\begin{array}{l}\text { Beautification and design of green } \\
\text { spaces }\end{array}$ & 432 \\
\hline 10 & $\begin{array}{l}\text { Diversification of green space } \\
\text { applications }\end{array}$ & 427 & Biodiversity & 421 \\
\hline 11 & $\begin{array}{c}\text { Beautification and design of green } \\
\text { spaces }\end{array}$ & 415 & Dense planting & 406 \\
\hline
\end{tabular}

Source: compiled by author

As the above table shows, all key drivers and factors affecting optimal planning of urban green spaces include following factors: managerial and institutional, proper locating for ecological development of green spaces, provision of sustainable water resources, maintenance and protection of green spaces, proper access for all citizens, Green space continuity, restoration of barren lands, dense planting, biodiversity, Beautification and design of green spaces.

Therefore, by taking into account these key factors in urban green spaces development scenarios, ecological development of green spaces and thus sustainable development in cities can be achieved.

The following diagram represents weight of key factors in the development of green spaces, which were effective directly and indirectly.

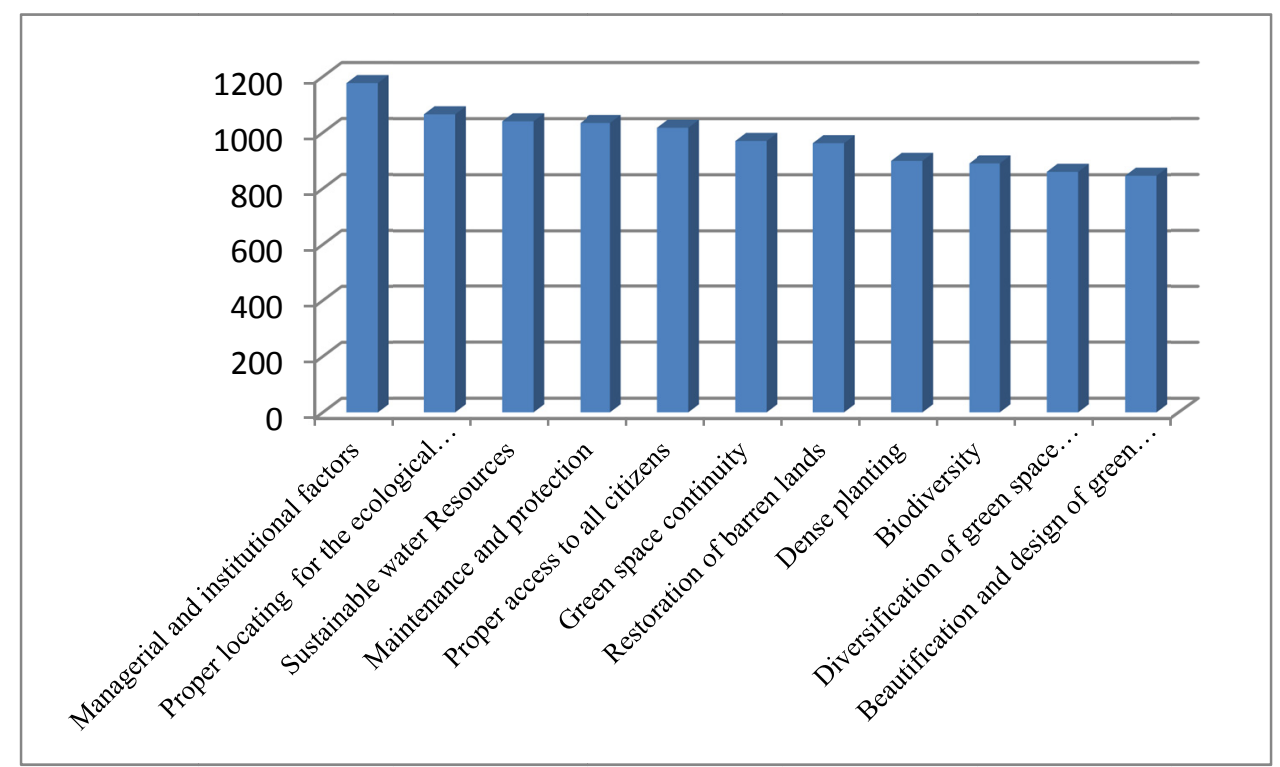

Figure (8). Factors with the highest impact rating with sum of weights of direct and indirect impact

Source: compiled by author

In both cases of direct and indirect effects, key factors have the highest weight compared with other factors, which is due to high importance of these factors in green spaces system of Tabriz metropolitan. 


\section{Conclusion}

According to studies, following accelerating construction process in Tabriz metropolitan, especially in recent decades, the city suffered from severe damage in terms of ecologically important elements, particularly regarding green spaces and has lost these valuable spaces day by day to the benefit of economic gains(in terms of urban planning and urban physical development).

To resolve shortage of natural green spaces in cities, having a systematic and structured approach to the development of urban green spaces for present and future are necessary for proper planning for such spaces. Tabriz city with a high population density as well as having an increased density of housing and a variety of industrial and municipal facilities and equipment; requires a qualitative and quantitative improvement of urban green spaces in line with increasing ecological and social functions of these spaces.

In this study, using Delphi method after opinion polling relevant experts in the planning of urban green spaces, factors and variables involved in the development of green spaces were extracted and then driving and key factors for the future development of green spaces were specified after weighting, according to experts in MICMAC software.

Structural planning for the future development of urban green spaces, all factors involved in the planning of green spaces are considered like a system with intertwined elements and in the form of a structure. Moreover, associations between these factors are evaluated and factors with higher effect are extracted. These superior factors are used to plan the development of green areas so that ecological structure of urban green spaces bring sustainable development for the city in the best way. In order to achieve this goal, all components of natural, socio - cultural, ecological, economic, physical and urban landscape factors are involved as a system.

Finally, eleven factors; "managerial and institutional, proper locating for ecological development of green spaces, provision of sustainable water resources, maintenance and protection of green spaces, proper access for all citizens, Green space continuity, restoration of barren lands, dense planting, biodiversity, Beautification and design of green spaces" were determined among key factors for the future development of green spaces in Tabriz City and structural development of urban green spaces for present and future requires taking into account these key factors are in the planning process. If these key factors are coherently and systematically planned for the future development of green spaces in the city of Tabriz, they will help to creating perfect green spaces and substantially reduce environmental problems and consequently social and psychological problems in the city of Tabriz.

\section{References}

Alizadeh, S. d., \& Salehifard, M. (2008). Analysis of the social and psychological aspects of green spaces in urban areas (urban management approach). Civil Administration Journal, 21.

Arcade, J., Godet, M., Meunier, F., \& Roubelat, F. (2003). Structural Analysis with the MICMAC method \& Actors Strategy with MACTOR method, the Millennium Project, Laboratory for Investigation Prospective and Strategy (LIPS).

Barbosa, O. et al. (2007). Who benefits from access to green space? A case study from Sheffield, UK, Landscape and Urban Planning Journal. http://dx.doi.org/10.1016/j.landurbplan.2007.04.004

Beheshti rouy, M. (2012). Analysis of the location of city Promenade in Iran, with an emphasis of Tabriz city recreational areas (Ph.d thesis). Faculty of Geography and Planning, University of Tabriz.

Feng, L. et al. (2004). Comprehensive concept planning of urban greening based on ecological principles: a case study in Beijing, China. Landscape and urban planning, 4. http://dx.doi.org/10.1016/j.landurbplan.2004.04.002

Forman, R. T. T., \& Gordo, M. (1986). Landscape ecology. John Wiley \& Stones, New York.

Godet, M. (2006). Strategic Foresight, Prospective, Problems and Methods. www.laprospective.fr.

Gomez, F., \& Salvador, P. (2006). A proposal for green planning in cities. Journal of sustainable development and planning, 1(1). 91-109. https://doi.org/10.2495/SDP-V1-N1-91-109

Jim, C.Y., \& Chen, W. Y. (2008). Pattern and divergence of tree communities in Taipei's main urban green spaces. $\begin{array}{lllll}\text { Journal of Landscape and Urban Planning, } & \text { 312-323. }\end{array}$ http://dx.doi.org/10.1016/j.landurbplan.2007.09.001

Johnson, B., \& Hill, K. (2002). Ecology and Design: Frameworks for Learning. Island Press.

Mahmoudzadeh, H. (2014). Analysis and Assessment of Ecological spatial development of Tabriz (Ph.d thesis). 
Faculty of Geography and Planning, University of Tabriz.

Omran, A., Khorish, M., \& Saleh, M. (2014). Structural Analysis with Knowledge- based MICMAC Approach. Journal of Computer application, 86(5).

Rabbani, T. (2012). Structural analysis, a tool for identifying and analyzing the factors affecting the future of urban issues. Proceedings of the First National Conference on futures, Tehran.

Rahimi, A. (2012). Assessment of spatial - physical development with an emphasis on infill development, case study: Tabriz city (Ph.d thesis). Faculty of Geography and Planning, University of Tabriz.

Shah Md. Atiqul Haq. (2011). Urban Green Spaces and an Integrative Approach to Sustainable Environment. Journal of Environmental Protection, 2, 601-608. https://doi.org/10.4236/jep.2011.25069

Shahivandi, A. (2006). Locating of urban green space, (case study: Khorramabad) (M. A thesis in geography and urban planning, Faculty of Literature and Humanities, Isfahan University).

Thaiutsa, B. et al. (2008). Urban green space, street tree and heritage large Tree assessment in Bangkok, Thailand. Urban Foresty and Urban Greening, 7(3), 219-229. http://dx.doi.org/10.1016/j.ufug.2008.03.002

Tjallingii, S. (2003). Green and red: enemies or allies? The Utrecht experience with green structure planning. Built Environment, 29(2), 107-116. https://doi.org/10.2148/benv.29.2.107.54466

Waldheim, C. (2006). The landscape urbanism reader. New York: Princeton Architectural Press.

Zangiabadi, Aand Rakhshani nasab, H. (2009). Analysis of Statistical - Spatial Urban Green Space Development Indices, Case Study: Isfahan urban areas. Ecology Journal, 49.

\section{Copyrights}

Copyright for this article is retained by the author(s), with first publication rights granted to the journal.

This is an open-access article distributed under the terms and conditions of the Creative Commons Attribution license (http://creativecommons.org/licenses/by/4.0/). 